Rafał Dubowski

\title{
Ochrona miejsc pochówku bohaterów narodowych de lege lata i de lege ferenda ${ }^{1}$
}

\begin{abstract}
Protection of burial sites of National Heroes de lege lata and de lege ferenda: According to the author of the opinion the request contained in the petition should be considered justified, and the bill submitted along with the petition, despite minor deficiencies, may be a starting point for a legislative work. The current provisions do not ensure a proper protection of burial places of the National Heroes, because they enable the cemetery manager to rearrange the grave after 20 years from the burial, if unless anyone objects to it and pays the burial fee.
\end{abstract}

Keywords: cemetery, Institute of National Remembrance, petition

Słowa kluczowe: cmentarz, Instytut Pamięci Narodowej, petycja

Doktor nauk prawnych, ekspert ds. legislacji BAS - rafal.dubowski@sejm.gov.pl https://orcid.org/0000-0001-7852-4275

\section{Treść i cel petycji}

Przedmiotem petycji jest żądanie podjęcia prac ustawodawczych nad załączonym do petycji projektem ustawy o zapewnieniu godnej pamięci i należytej ochrony miejscom spoczynku bohaterów powstania warszawskiego oraz innych osób zasłużonych w walkach o niepodległość i suwerenność państwa polskiego.

Opinia prawna na temat petycji dotyczacej potrzeby wystapienia $z$ inicjatywa ustawodawcza w celu zapewnienia godnej pamięci i należytej ochrony miejscom pochówku Bohaterów Powstania Warszawskiego i innych Bohaterów Narodowych zastużo$n y c h$ walkach o suwerenność i niepodległość Rzeczypospolitej Polskiej sporządzona 28 września 2018 r. na zlecenie przewodniczącego Komisji do Spraw Petycji; BAS-WAP 2194/18. 


\section{Czy petycja mieści się w zakresie zadań i kompetencji adresata petycji (art. 2 ust. 3 ustawy o petycjach)?}

Petycja dotyczy zmiany ustawy przez Sejm. Zgodnie z art. 95 ust. 1 Konstytucji RP władzę ustawodawczą w Rzeczypospolitej Polskiej sprawują Sejm i Senat. Natomiast stosownie do art. 118 ust. 1 Konstytucji RP inicjatywa ustawodawcza przysługuje m.in. posłom. Artykuł 32 ust. 2 regulaminu Sejmu, w związku $\mathrm{z}$ art. 112 Konstytucji RP, precyzuje, że poselskie projekty ustaw mogą być wnoszone przez komisje sejmowe lub grupę co najmniej 15 posłów podpisujących projekt. Uwzględniając powyższe, należy uznać, że petycja mieści się w zakresie zadań i kompetencji Sejmu.

\section{Wymogi formalne (art. 4 ust. 1 i 2 ustawy o petycjach)}

Petycja spełnia wymogi formalne określone w art. 4 ust. 1 i 2 ustawy o petycjach.

\section{Kwestie uznane za istotne w związku z petycją}

Strzeżenie dziedzictwa narodowego jest przede wszystkim wyrazem wdzięczności za to, co naród otrzymał od swoich przodków. Tym, którzy już odeszli, wdzięczność tę można okazać w szczególności, troszcząc się o ich groby i miejsca spoczynku. Bez wątpienia ten akt podziękowania należy się wszystkim bohaterom walk o suwerenność i niepodległość Rzeczypospolitej Polskiej. Zazwyczaj w opiekę nad grobami i miejscami spoczynku tych osób zaangażowani są ich krewni, przyjaciele, koleżanki i koledzy. Ogromne dokonania na tym polu mają również organizacje społeczne. Przedstawiony wraz z petycją projekt ustawy stwarza w tym zakresie jednak szczególną możliwość. Ponieważ w świetle Konstytucji RP naród sprawuje władzę przez swych przedstawicieli, akt prawny tej treści byłby swego rodzaju aktem wdzięczności całego narodu.

Jak trafnie zauważają autorzy petycji, obowiązujące obecnie przepisy nie zapewniają należytej ochrony miejscom spoczynku bohaterów narodowych, bowiem umożliwiają zarządcy cmentarza ponowne rozporządzenie grobem ziemnym po upływie 20 lat od pochówku, jeżeli jakakolwiek osoba nie zgłosi zastrzeżenia przeciw temu i nie uiści opłaty przewidzianej za pochowanie zwłok². Ponadto, na co też słusznie zwrócono uwagę w petycji, właściwej ochrony nie zapewnia art. 7 ust. 5 ustawy o cmentarzach, który zakazuje użycia do ponownego pochowania grobów, mających wartość pamiątek historycznych, ponieważ brak

2 Zob. art. 7 ust. 1-3 ustawy z 31 stycznia 1959 r. o cmentarzach i chowaniu zmarłych, t.j. Dz.U. 2017, poz. 912; dalej ustawa o cmentarzach. 
jest regulacji, które wskazywałyby, na jakich zasadach i w jakim trybie dochodzi do zakwalifikowania konkretnego grobu jako tego rodzaju pamiątki.

Podzielając zapatrywania autorów petycji co do potrzeby wprowadzenia odpowiednich zmian ustawodawczych, warto jednak zwrócić uwagę na kilka kwestii szczegółowych, które mogłyby ułatwić ewentualne prace nad przedstawionym projektem.

\section{Preambuła}

Biorąc pod uwagę, że w procesie ustawodawczym oprócz Sejmu RP uczestniczą także inne podmioty, warto rozważyć modyfikację zdania pierwszego preambuły, które rozpoczyna się od słów: „Sejm Rzeczypospolitej stwierdza...”. Należy wyjaśnić, że tekst preambuły często zaczyna się od czasownika w formie imiesłowu przysłówkowego współczesnego i tego rodzaju rozwiązanie można byłoby zastosować w projekcie, który przedłożono wraz z petycjąa ${ }^{3}$. Aczkolwiek trzeba również zaznaczyć, że nie jest tak, iż formuła zaproponowana przez autorów petycji nie występuje w polskim ustawodawstwie. Przyjęto ją np. w preambule ustawy z 24 stycznia 1991 r. o kombatantach oraz niektórych osobach będących ofiarami represji wojennych i okresu powojennego (t.j. Dz.U. 2018, poz. 276; dalej: ustawa o kombatantach).

\section{Artykuł 2 projektu}

Ustęp 1 tego artykułu przewiduje, że: [p]rzepisy niniejszej ustawy stosuje się do miejsc spoczynku osób, które brały czynny udział w Powstaniu Warszawskim, a także do miejsc spoczynku innych osób, o których mowa w art. 1 ust. 1 ustawy z 28 marca 1933 r. o grobach i cmentarzach wojennych (Dz.U. z 2017 r. poz. 681 oraz z 2018 r. poz. 369) lub w art. 1-4 ustawy z 24 stycznia 1991 r. o kombatantach oraz niektórych osobach będacych ofiarami represji wojennych i okresu powojennego (Dz.U. z 2018 r. poz. 276).

Ze względu na to, że celem projektowanej ustawy jest okazanie wdzięczności i upamiętnienie osób zasłużonych w walkach o suwerenność i niepodległość państwa polskiego, należy w tym miejscu zauważyć, że art. 2 ust. 1 projektu może utrudnić realizację tego celu, bowiem obejmuje on ochroną miejsca spoczynku wskazanych w nim osób niezależnie od ich zasług. Wydaje się, iż nie można zakładać, że wszystkie osoby pochowane w grobach wojennych, o których mowa w art. 1 ust. 1 ustawy z 28 marca 1933 r. o grobach i cmentarzach wojennych (t.j.

Zob. np. początek preambuły do ustawy z 6 marca 2018 r. - Prawo przedsiębiorców

(Dz.U. poz. 646): Kierując się konstytucyjna zasada wolności działalności gospodarczej...; ustawy z 7 stycznia 1993 r. o planowaniu rodziny, ochronie płodu ludzkiego i warunkach dopuszczalności przerywania ciąży (Dz.U. nr 17, poz. 78, ze zm.): Uznajacc, że życie jest fundamentalnym dobrem człowieka... oraz ustawy z 18 grudnia 1998 r. o Instytucie Pamięci Narodowej - Komisji Ścigania Zbrodni Przeciwko Narodowi Polskiemu (Dz.U. 2016, poz. 1575, ze zm.): Mając na względzie... 
Dz.U. 2017, poz. 681; dalej: ustawa o grobach wojennych), zasłużyły się w czasie walk o niepodległość i suwerenność państwa polskiego. Ad exemplum: art. 1 ust. 1 tej ustawy mówi, iż grobami wojennym są m.in.: groby $i$ miejsca spoczynku osób wojskowych, poległych lub zmarłych z powodu działań wojennych, bez względu na narodowość, co pozwala uznać za groby wojenne także groby i miejsca spoczynku osób, które walczyły przeciwko państwu polskiemu4 ${ }^{4}$ Oczywiście $\mathrm{w}$ praktyce stosowania (obecnie projektowanego) art. 2 ust. 1, posługując się wykładnią celowościową, zasadnie można byłoby przyjąć, że nie odnosi się on do miejsc spoczynku tych osób. Niemniej trzeba w tym miejscu podkreślić, że takiego wniosku bynajmniej nie można wyprowadzić z literalnego brzmienia tego przepisu.

O ile w przedstawionym wyżej przypadku wykładnia celowościowa pozwalałaby wyeliminować wskazany mankament projektowanej regulacji, o tyle $\mathrm{w}$ innych sytuacjach mogłaby ona okazać się niewystarczająca. Warto bowiem zauważyć, że również nie sposób przyjąć, iż ustawodawca przesądził o tym, że wszystkie osoby wskazane w art. 1-4 ustawy o kombatantach powinny - ze względu na swoje zasługi - korzystać ze szczególnych uprawnień. Potwierdza to przede wszystkim art. 21 ustawy o kombatantach. Ustęp 1 tego artykułu stanowi, że: [u]prawnienia określone w ustawie przysługują osobie, która uzyska decyzje potwierdzająca działalność wymieniona wart. 1 ust. 2 i w art. 2 albo fakty, o których mowa w art. 4, posiada obywatelstwo polskie lub posiadała je $w$ okresie działalności kombatanckiej bądź w okresie podlegania represjom, z zastrzeżeniem ust. 2. Natomiast art. 21 ust. 2 ustawy o kombatantach przewiduje, że uprawnienia, o których mowa w poprzednim ustępie tego artykułu, nie przysługuja osobie, która:

1) w okresie wojny 1939-1945 kolaborowała z hitlerowskim okupantem;

2) przymusowo petniła służbę $w$ armii niemieckiej lub dobrowolnie zadeklarowała odstępstwo od narodowości polskiej, jeżeli potem do końca wojny nie brała udziału $w$ walce o niepodległość Polski;

$\left.2^{1}\right)$ kolaborowała $z$ radzieckimi władzami okupacyjnymi w latach 1939-1941;

3) w okresie od września 1939 r. do końca 1956 r. służyła w NKWD albo w innych organach represji ZSRR działajacych przeciwko Narodowi i Państwu Polskiemu;

4) $w$ latach 1944-1956:

a) pełniła służbę lub funkcję i była zatrudniona w strukturach Urzędów Bezpieczeństwa, Stużby Bezpieczeństwa i Informacji Wojskowej, a także nadzorujących je komórkach jednostek zwierzchnich związanych ze stosowaniem represji wobec osób działających na rzecz suwerenności i niepodległości Rzeczypospolitej Polskiej,

4 Potwierdza to także art. 2 tej ustawy, który stanowi, że: Groby wojenne bez względu na narodowość i wyznanie osób, w nich pochowanych, oraz formacje, do których osoby te należały, mają być pielegnowane i otaczane należnym tym miejscom szacunkiem i powaga. 
b) była zatrudniona, petniła służbę lub funkcję $w$ jednostkach organizacyjnych lub na stanowiskach zwiazzanych ze stosowaniem represji wobec osób podejrzanych lub skazanych za działalność podjętą na rzecz suwerenności i niepodległości Rzeczypospolitej Polskiej:

- w organach prokuratury i prokuraturze wojskowej,

- w sadownictwie powszechnym lub wojskowym,

- w stużbie więziennej,

c) była zatrudniona, pełniła służbę lub funkcję w aparacie bezpieczeństwa publicznego poza strukturami Urzędów Bezpieczeństwa, Służby Bezpieczeństwa lub Informacji Wojskowej, jeżeli podczas i w związku z ta działalnościa wykonywała zadania śledcze i operacyjne związane bezpośrednio ze zwalczaniem organizacji oraz osób działających na rzecz suwerenności i niepodległości Rzeczypospolitej Polskiej,

d) była funkcjonariuszem organów bądź jednostek organizacyjnych Polskiej Partii Robotniczej lub Polskiej Zjednoczonej Partii Robotniczej, do których właściwości rzeczowej - terenowej i centralnej - należał nadzór nad instytucjami, o których mowa w lit. a i b, badź nad zadaniami, o których mowa w lit. c;

5) uchybiła godności obywatela polskiego, wykorzystując władze otrzymana od instytucji stosujących represje do ciemiężenia wspólwięźniów;

6) uchybiła godności obywatela polskiego, donosząc władzom komunistycznym o żotnierzach podziemia, legionistach, organizacjach podziemnych, partyzanckich i tych wszystkich, których obejmują art. 2 i 4 ;

7) dopuściła się zabójstwa lub innej zbrodni wobec osób cywilnych w okresie do 31 grudnia 1956 r. w związku z działalnościq uznana za działalność kombatancka lub równorzędna $w$ rozumieniu ustawy, za co została skazana prawomocnym wyrokiem sądu.

Chociaż nie ulega wątpliwości, że celem przedłożonego projektu ustawy jest okazanie wdzięczności i upamiętnienie osób zasłużonych w walkach o suwerenność i niepodległość państwa polskiego, to jednak przedstawione w nim rozwiązania nie pozwalają rozstrzygnąć, czy jego postanowienia winny być stosowane do miejsc spoczynku osób, które, mimo tego że spełniają kryteria określone w art. 1-4 ustawy o kombatantach, w jakimś okresie życia podjęły działalność, o której mowa w art. 21 ust. 2 ustawy o kombatantach. Innymi słowy, w świetle art. 2 ust. 1 projektu oraz pozostałych jego przepisów nie jest jasne, czy do objęcia ochroną określonego grobu wyłącznie wystarczy, aby spoczywająca w nim osoba zasłużyła się w walkach o suwerenność i niepodległość Polski, czy również niezbędne jest to, aby nigdy nie podjęła działalność godzącej w te wartości.

Warto zauważyć, że autorzy petycji proponują wykorzystać odesłanie do art. 2 ust. 1 projektu w przepisach kilku innych aktów prawnych. I tak np. po wprowadzeniu postulowanych zmian art. 7a ust. 1 ustawy o cmentarzach (zob. art. 4 pkt 2 projektu) upoważniałby Prezesa Instytutu Pamięci Narodowej do wydania decyzji o zakazie użycia grobu do ponownego pochowania w przypadku, 
gdy spoczywa w nim osoba, o której mowa w art. 2 ust. 1 projektowanej ustawy, natomiast art. $262 \$ 1$ a ustawy z 6 czerwca 1997 r. - Kodeks karny przewidywałby sankcje karne za znieważenie zwłok, prochów lub miejsca spoczynku osoby, o której mowa w art. 2 ust. 1 (zob. art. 5 projektu).

W związku z powyższym, mając na uwadze, że wykładnia art. 2 ust. 1 istotnie wpływałaby zarówno na stosowanie przepisów merytorycznych projektowanej ustawy, jak i zmienianych przepisów innych ustaw, wydaje się, że w razie podjęcia prac nad regulacją przedstawioną $\mathrm{w}$ petycji, warto byłoby rozważyć możliwość doprecyzowania art. 2 ust. 1.

\section{Artykuł 3 projektu}

$\mathrm{W}$ treści tego przepisu zamiast „Z zachowaniem uprawnień przysługującym kościołom i innym związkom wyznaniowym” winno być: „Z zachowaniem uprawnień przysługujących kościołom i innym związkom wyznaniowym".

\section{Artykuł 4 projektu (Decyzja o zakazie użycia grobu do ponownego pochowania)}

Przepis ten wprowadza zmiany w ustawie o cmentarzach. Zaproponowana nowelizacja m.in. umożliwiałaby Prezesowi Instytutu Pamięci Narodowej wydanie decyzji o zakazie użycia grobu do ponownego pochowania w przypadku, gdy spoczywa w nim osoba, o której mowa w art. 2 ust. 1 projektu.

Kwestie związane $\mathrm{z}$ wykorzystaniem grobu do ponownego pochowania uregulowane zostały m.in. w art. 7 ust. 1-3 ustawy o cmentarzach. Według ust. 1 tego artykułu grób nie może być użyty do ponownego chowania przed upływem lat 20. Niemniej, jak stanowi art. 7 ust. 2: [p]o uptywie lat 20 ponowne użycie grobu do chowania nie może nastąpić, jeżeli jakakolwiek osoba zgłosi zastrzeżenie przeciw temu i uiści opłatę, przewidziana za pochowanie zwłok. Zastrzeżenie to ma skutek na dalszych lat 20 i może być odnowione. Zgodnie z ust. 3 art. 7 wskazane przepisy nie mają zastosowania do chowania zwłok w grobach murowanych przeznaczonych do pomieszczenia zwłok więcej niż jednej osoby, a także do chowania urn zawierających szczątki ludzkie powstałe w wyniku spopielenia zwłok.

Mając na uwadze przedstawione rozwiązania ustawy o cmentarzach, należy zauważyć, że zakaz użycia grobu do ponownego pochowania, o którym mowa w art. 7 ust. 1, ma nieco innych charakter niż ten, który wynika $z$ art. 7 ust. 2. Artykuł 7 ust. 1 wyklucza dochowanie kolejnej osoby do grobu (o ile nie zachodzą okoliczności, o których mowa w art. 7 ust. 3) przed upływem 20 lat. Natomiast, jak stwierdził Sąd Najwyższy w wyroku z 21 października 2010 r.: [p] rawidłowa wykładnia tego przepisu [tj. art. 7 ust. 2 ustawy o cmentarzach - dopisek R.D.], $z$ dziedziny prawa publicznego, prowadzi do wniosku, że złożenie zastrzeżenia i uiszczenie opłaty po upływie dwudziestu lat od poprzedniego pochówku skutkuje nabyciem prawa do wykorzystania miejsca, które to prawo pozostaje wiążace tylko w stosunku do zarządcy cmentarza. Nabyte prawo wyraża się więc tylko możnościa 
domagania się niesprzeciwiania się przez zarządcę wykonaniu kolejnego pochówku oraz niesprzeciwiania się stanowi powstałemu w wyniku tej czynności [...] Przepis nie zawiera [...] stwierdzenia, że osoba dokonująca opłat staje się dysponentem grobu, sens przepisu, jak przedstawiono, sprowadza się do uniemożliwienia zarzadcy cmentarza rozporzadzenia grobem przez kolejnych 20 lat. Nabyte przez złożenie zastrzeżenia $i$ przez dokonanie opłaty za pochowanie zwłok prawo nie daje swobody decyzji czy i kto powinien być pochowany. To uprawnienie pozostaje wspólne dla osób bliskich zmarłego, wynika bowiem z własnego prawa osobistego $k a \dot{z}$ dej $z$ tych osób. Innymi słowy, art. 7 ust. 2 ustawy o cmentarzach, który mówi o zakazie użycia grobu do ponownego pochowania inaczej niż art. 7 ust. 1 tego aktu prawnego, który także taki zakaz ustanawia, umożliwia osobom bliskim zmarłego dochowanie kolejnej osoby do grobu po upływie 20 lat.

Ponadto, jak już wyżej wskazano, zgodnie z art. 7 ust. 3 ustawy o cmentarzach, art. 7 ust. 1 i 2 tego aktu prawnego nie mają zastosowania do chowania zwłok w grobach murowanych przeznaczonych do pomieszczenia zwłok więcej niż jednej osoby, a także do chowania urn zawierających szczątki ludzkie powstałe w wyniku spopielenia zwłok. A więc, wynika z tego m.in., że w przypadkach, o których mowa w art. 7 ust. 3, bliscy zmarłego mogą dochować do grobu kolejne osoby przed upływem 20 lat.

W związku z powyższym być może warto byłoby w projekcie doprecyzować, jaki skutek miałby zakaz wykorzystania grobu do ponownego pochówku wynikający z decyzji Prezesa Instytutu Pamięci Narodowej i w ten sposób rozstrzygnąć, czy (i ewentualnie, w jakich sytuacjach) po wydaniu tej decyzji dopuszczalne byłoby dochowanie kolejnych osób.

\section{Procedura wydawania decyzji}

$\mathrm{W}$ art. 4 projektu proponuje się wprowadzić do ustawy o cmentarzach przepisy dotyczące postępowania w sprawie zakazu użycia grobu do ponownego pochowania. Jednocześnie dodawany do tej ustawy art. 7a ust. 3 przesądzałby, że do wydania decyzji w tym przedmiocie nie stosuje się przepisów ustawy z 14 czerwca 1960 r. - Kodeks postępowania administracyjnego (t.j. Dz.U. 2017, poz. 1257, ze zm.; dalej: k.p.a.). Biorąc jednak pod uwagę, że przepisy proceduralne zaproponowane $\mathrm{w}$ projekcie nie regulują postępowania $\mathrm{w}$ sprawie wydania decyzji o zakazie ponownego użycia grobu w sposób kompleksowy, całkowite wyłączenie stosowania przepisów Kodeksu postępowania administracyjnego może budzić pewne wątpliwości. Na przykład art. 7a ust. 5 ustawy o cmentarzach po zmianach stanowiłby: Decyzja, o której mowa w ust. 1, zawiera uzasadnienie faktyczne i prawne, pouczenie o prawie do wniesienia skargi do sqdu administracyjnego, o której mowa w ust. 7, i podlega doręczeniu właściwemu wojewodzie oraz wójtowi (burmistrzowi, prezydentowi miasta) lub związkowi wyznaniowemu. W przypadkach, gdy decyzja została wydana na wniosek podmiotu, o którym mowa $w$ ust. 2, podlega doręczeniu również wnioskodawcy. Mając na uwadze, że 
postanowienia Kodeksu postępowania administracyjnego nie mogą być stosowane, należy stwierdzić, że z projektowanych przepisów wynika, iż decyzja ta nie powinna zawierać elementów, o których mowa w art. $107 \$ 1$ k.p.a., a więc np.: daty, podstawy prawnej czy też podpisu z podaniem imienia i nazwiska osoby, która wydała decyzję.

Poza tym projektowany art. 7a ust. 4 ustawy o cmentarzach przewiduje miesięczny termin, w którym wskazane w nim podmioty mogą wyrazić opinię w sprawie zasadności wydania decyzji o zakazie użycia grobu do ponownego pochowania. Jednakże to właśnie art. 57 k.p.a., którego stosowanie byłoby wyłączone, określa, jak poszczególne terminy należy liczyć.

Mając powyższe na względzie, wydaje się, że wyłączenie stosowania przepisów Kodeksu postępowania administracyjnego nie jest właściwym rozwiązaniem. Na gruncie postępowań o charakterze szczególnym odpowiednie stosowanie regulacji kodeksowych ma wszak za zadanie zapobiegać występowaniu luk. W związku z tym w toku prac nad projektem należałoby rozważyć, jakie postanowienia Kodeksu postępowania administracyjnego powinny być stosowane odpowiednio w postępowaniu w sprawie wydania decyzji o zakazie użycia grobu do ponownego pochowania i ewentualnie następnie wyłączyć stosowanie tylko niektórych regulacji zawartych w tym akcie prawnym.

\section{Artykuł 5 projektu}

Przepis ten przewiduje, że w ustawie z 6 czerwca 1997 r. - Kodeks karny (t.j. Dz.U. 2017, poz. 2204, oraz 2018, poz. 20, 305 i 663; dalej: k.k.), w art. 262 po $\$ 1$ dodaje się $\$ 1$ a i $\$ 1$ b w brzmieniu: $\$ 1$. Kto znieważa zwłoki, prochy lub miejsce spoczynku osoby, o której mowa w art. 2 ust. 1 ustawy z ... o zapewnieniu godnej pamięci i należytej ochrony miejscom spoczynku Bohaterów Powstania Warszawskiego oraz innych osób zasłużonych $w$ walkach o niepodległość i suwerenność Państwa Polskiego (Dz.U. poz....), podlega karze grzywny, ograniczenia wolności albo karze pozbawienia wolności do lat 3. $\$ 1 b$. W razie skazania za przestępstwo określone $w \$ 1$ la sąd może orzec nawiązkę na wskazany cel społeczny, związany z ochrona miejsc spoczynku Bohaterów Powstania Warszawskiego oraz innych osób zasłużnych $w$ walkach o niepodległość i suwerenność Państwa Polskiego, w szczególności na rzecz organizacji społecznej zajmującej się upamiętnianiem i otaczaniem opieka miejsc pamięci narodowej.

Warto zauważyć, że projektowany art. 262 po $₫ 1$ a nie tylko penalizowałby znieważenie grobu (lub złożonych w nim zwłok lub prochów) wtedy, kiedy grób ten w chwili popełnienia czynu byłby objęty szczególną ochroną na mocy decyzji administracyjnej, o której mowa w art. 4 pkt 2 projektu, ale także w przypadku gdy w chwili popełnienia czynu decyzja taka nie funkcjonowałaby w obrocie prawnym mimo tego, że w danym grobie pochowano osobę, o której mowa w art. 2 ust. 1 projektowanej ustawy (wszak niewydanie tej decyzji mogłoby tłumaczyć np. to, że postępowanie w danej sprawie nie zostało zakończone albo 
w ogóle nie zostało wszczęte). Rozwiązanie przyjęte w projekcie wydaje się słuszne, bowiem nie uzależniania intensywności prawnokarnej ochrony od tego, czy wydano decyzję o zakazie użycia grobu do ponownego pochowania, lecz od tego, czy w grobie spoczywa osoba, która brała udział w walkach o suwerenność i niepodległość państwa polskiego. Ewentualny brak wiedzy sprawcy o zasługach osoby pochowanej byłby okolicznością mającą w praktyce niemałe znaczenie przy ustalaniu, czy czyn popełniono (nie)umyślnie.

Reasumując tę część opinii, należy wskazać, że projektowany art. 5 sam w sobie nie budzi zastrzeżeń, jednak mając na uwadze wymóg określoności przepisów karnych, warto w tym miejscu jeszcze raz zasygnalizować potrzebę doprecyzowania art. 2 ust. 1 projektu w ten sposób, aby wiadomo było, w jaki sposób na kwalifikację prawną czynu wpływać będzie fakt, że osoba, o której mowa w art. 2 ust. 1, w pewnym okresie życia podejmowała działania godzące w suwerenność i niepodległość państwa polskiego.

Aby ułatwić dalsze prace nad projektem, na marginesie można dodać również, że po opracowaniu projektu został opublikowany tekst jednolity Kodeksu karnego i dlatego w art. 5 należałoby - zgodnie z $\$ 158$ ust. 1 w związku z $\$ 161$ rozporządzenia Prezesa Rady Ministrów z 20 czerwca 2002 r. w sprawie „Zasad techniki prawodawczej” (t.j. Dz.U. 2016, poz. 283) - zmienić oznaczenie dziennika urzędowego i zamiast „Dz.U. z 2017 r. poz. 2204 oraz z 2018 r. poz. 20, 305 i 663” wskazać „Dz.U. z 2018 r. poz. 1600”.

\section{Wnioski}

Żądanie zawarte w petycji należałoby uznać za uzasadnione, a przedstawiony wraz z petycją projekt ustawy, mimo drobnych niedociągnięć, może stanowić punkt wyjścia do prac legislacyjnych. 